\title{
Development of the sphere of recreation and tourism - direction of digital transformation "Smart City"
}

\author{
A. Baranova ${ }^{1}$ and $E$. Vorobey ${ }^{1, *}$ \\ ${ }^{1}$ Sochi State University, Plastunskaya st., 94, 354003, Sochi, Russia
}

\begin{abstract}
The concept of "smart city" is becoming more and more popular. Analysis of the literature showed that the meaning of the word "smart city" is multifaceted. The authors are similar in that the implementation of tasks under the concept of "smart city" will lead to economic growth of the territory and achieve high quality of life through the active introduction of information technology in the processes of life support. The majority of publications deal with the development of a "smart city" as a municipality and provide a method of ranking them by digitalization levels. This article uses the example of the recreation and tourism sector as an example to offer an assessment of digitalization within the industry, which will reveal competitive organizations within the industry. The article substantiates that the sphere of recreation and tourism as a direction of digital transformation of "smart resort" is a driver of development and implementation of IT technologies. And this will lead to the future development of "smart city" as a whole.
\end{abstract}

\section{Introduction}

Before identifying and justifying the digital transformation of the sphere of recreation and tourism, let us consider the essence of the concept of "smart city". It is considered that the term "Smart", introduced by the American scientist Peter Ferdinand Drucker in his work "The Practice of Management" (1954), is an acronym: S - specific, M - measurable, A - achievable, Realistic, T (Time) - determined in time [1].

1) In terms of technological prosperity of municipalities, a "smart city" is:

2) The concept of integrating information technology and the Internet to manage all areas of the metropolis [2];

3) organic connection between technological, human and institutional components, where social factors other than smart technologies are central [3];

4) a set of six components: Smart Economy (ability to transform entrepreneurship, labor market, integration into the international market); Smart Mobility (availability of modern and safe transportation); Smart Governance (public participation in decision-making processes, availability of public services); Smart Environment (attractiveness of natural conditions, lack

\footnotetext{
* Corresponding author: vorobei.sochi@yandex.ru
} 
of pollution); Smart Living (improving the quality of life, availability of cultural, medical, tourist, educational and other services); Smart People (improving the level of human skills, creativity, tolerance, cosmopolitanism) [4];

5) Effective integration of planning, management and "smart" approaches to development. Through the management of the digital network of urban geography, resources, environment, economic, social and other systems can achieve intelligent urban management [5];

6) a set of physical, social and business infrastructures [6];

7) a city with an emphasis on metabolism, culture and management [7];

8) joint use of program systems and network infrastructure to better connect the seven components of urban infrastructure and services: city administration, education, health care, public safety, real estate, transportation and utilities [8];

9) an interdisciplinary theme affecting the human, social, economic and technical fields of research [9];

10)a city with a population of over 100,000 people, where advanced digital and engineering technologies are being actively introduced, which increases the efficiency of the city management system, quality and satisfaction of residents' life [10].

The directions of digital transformation of urban economy are understood as key aspects of life and socio-economic development of smart cities, including [10,11]:

- urban management;

- innovations for the urban environment;

- intelligent public safety systems;

- communication network infrastructure;

- "smart" housing and communal services;

- "smart" urban transport;

- intellectual systems of ecological safety;

- tourism and service;

- intellectual systems of social services;

- economic condition and investment climate.

As a result of studying the works of Russian and Russian economists, we found that the "smart city" is a municipal entity, whose industries and activities are developed through the introduction of modern information and communication technologies, and in accordance with established indicators of digital transformation.

\section{Materials and methods}

The research was based on logical analysis methods, generalization and observation. Based on domestic and foreign authors (I.A. Vasilenko, A.N. Egorov, N.Y. Pivkina, T. Nam, T. A. Pardo, A. Vanolo, A. Su K, J. Lee, J. Fu H., C. Harrison, Eckman B., Hamilton R., Hartswick P., Kalagnanam J., Paraszczak J., Williams P., Allam Z., Newman P., Washburn D., Sindhu U., Balaouras S., Dines R.A., Hayes N., Nelson L.E., etc.) studied the concept of "smart city". The works of economists (E.V. Zhertovskaya, M.V. Yakimenko, D. Bukhalis, A. Amarangana, U. Gretzel, M. Sigala, Z. Xiang, A. Minov) served as a basis for considering the sphere of recreation and tourism as a direction of digital transformation.

\section{Results}

The first projects to create "smart cities" were implemented in European cities: Amsterdam, Barcelona, Lisbon, Vienna, London. Quantitative assessment of smart cities in Russia was carried out in 2017. National Research Institute of Technology and Communication (NITS), 
which developed its own methodology for the analysis of cities through the "Smart City Indicator NIITS". The researchers analyzed 15 largest Russian cities in seven key areas: smart economy, smart management, smart residents, smart technology, smart environment, smart infrastructure, smart finance. The result of the research was an opportunity to identify cities where technologies are developed at a high level - Moscow (1st place), St. Petersburg (2nd place) and cities where technologies are developing noticeably - Kazan (3rd place) and Yekaterinburg (4th place). In Russia, the project "Smart City" began to be implemented in 2018 in a pilot mode, and in 2019 became mandatory under two national projects "Housing and Urban Environment" and "Digital Economy". First of all, it is aimed at improving the competitiveness of Russian cities, creating comfortable living conditions and the formation of an effective system of urban management and is based on the following principles: human orientation, technologically sound urban environment, improving the quality of urban resource management, a comfortable environment, economic efficiency [12].

From the projects of "smart cities" appeared the concept of "smart tourism", used to describe the growing dependence of tourist areas and their industries on information and communication technologies, which ultimately contributes to the growth of competitiveness of the city and improve its image in the eyes of tourists [13, 14].

Introduction and use of Smart City technologies in urban development should involve not only providing comfortable living conditions for local people, but also creating and maintaining conditions for tourists to visit the city [1].

Today, tourism has become a special socio-cultural phenomenon that unites both the history of the country and the latest information technologies, primarily in the field of communications and territorial development. Due to this, the city, the region, the country will find a new attractive business card for tourists [2].

\section{Discussion}

According to the site https://russiasmartcity.ru on June 3, 2020 in Russia the first "smart" resort city Zheleznovodsk appeared. Its transformation was carried out in several areas urban management, tourism, logistics, housing and utilities, security. Through a mobile application or online portal, you can find out how many minutes the next bus will come, see the schedule of cleaning, control the flow of water in blowers, report on the problem situation. In the field of tourism for holidaymakers developed a mobile guide and tourist online portal [15].

According to the results of surveys in social networks most innovations for tourists have been implemented in Moscow, St. Petersburg and Sochi. In Sochi electronic guest cards have already been developed, on which tourists can get a discount on visiting municipal institutions and on purchases from commercial partners. Now there are activities to fill the navigation system on hiking routes [16].

In Sochi, applications are being developed: "My Sochi / Tour", which will include a register of tourist attractions, event calendar and an electronic assistant vacationer. In addition, applications are being developed: "My Sochi / apartment", "My Sochi / Investor", "My Sochi / Health", "My Sochi / Travel", "My Sochi / Nature" and other services [17].

The development strategy of the "smart city" of Sochi until 2030 was developed by the National Research Institute for Technology and Communications (NIITS) in 2017. Based on the analysis of the state of the city's socio-economic system and all its branches, the need to develop, first of all, the tourist complex and transport system, then the housing and utilities sector and other industries was identified. As for the sphere of recreation and tourism, a tourist portal of the city and the system of positioning of public transport have already been implemented [18]. 
According to the authors A. Baranova, T.G. Borisova, I.A. Vasilenko, E. Vorobey, A.N. Egorova, S. Kegeyan, Sochi has a fairly developed urban infrastructure, large resource potential and growth prospects as a competitive and "smart" resort. "Smart City" for tourists includes the creation of applications for tourists with monitoring of environmental conditions, availability of emergency communications, access to cultural heritage, transport accessibility, medical care and convenient payment for services [19-21].

Membership in the International Club of "smart cities" will allow Sochi to adapt more easily to innovative changes in medicine, tourism, transport structure and other industries. The resort will begin to implement modern technologies without having a negative impact on the economy, social sphere and environment. A "Digital Technology Showroom" may be created in Sochi. [22].

With the purpose of qualitative implementation of the Smart City Project, in 2019 the Ministry of Construction and Housing and Communal Services of the Russian Federation developed a Methodology of evaluation of the progress and efficiency of digital transformation of municipal services in the Russian Federation [10].

The city IQ Index is a digital value (in points) of the level of digital transformation of urban economy. The purpose of assessment of the IQ of cities is to assess and monitor on an annual basis the effectiveness of the digital transformation of urban economy.

The objectives of assessment of the index IQ of cities are:

- evaluation, comparison and ranking of cities in the Russian Federation on the level of digital transformation;

- to determine the main directions of the digital transformation of urban economy, affecting the socio-economic development of the municipality;

- evaluation of the efficiency and effectiveness of implementation of digital and engineering solutions;

- determination of priority directions of state support of municipal economy development.

Index IQ of the city is an integral index, which is calculated on the basis of the values of the subindexes that are an assessment of the development of 10 directions of digital transformation of the municipal economy innovation for the urban environment intellectual systems of public safety infrastructure communication networks " Smart urban transport intellectual systems of environmental safety tourism and service intellectual systems of social services.

Calculation of subindexes is carried out on the basis of indicator values, which are divided into two categories.

IQ $\ddot{U}$ (com) - general indicators of assessment of the level of development of directions of digital transformation of urban economy;

IQ Ü (sol) - indicators of evaluation of the level of development of advanced digital and engineering solutions, including:

- binary indicators to assess the presence or absence of advanced digital and engineering solutions in the city;

- quantitative indicators to assess the performance and scale of application of advanced digital and engineering solutions in the city.

The calculation of the sub-indices is presented in Table 1.

The indicators are evaluated on a scale from 1 to 12 points, where 1 point means minimum value, 12 points - maximum value. Binary indicators are scored on a scale from 0 to 1 depending on the number of assessed functionality, where 0 means absence of the corresponding functionality (specific feature, capability), 1 means its presence. 
Table 1. Calculation of evaluation sub-indexes for advanced digital and engineering solutions in the municipal economy as a whole.

\begin{tabular}{|c|c|c|}
\hline City IQ Index & $\begin{array}{l}\text { General indicators of } \\
\text { assessment of the level of } \\
\text { development of the } \\
\text { directions of digital } \\
\text { transformation of urban } \\
\text { economy }\end{array}$ & $\begin{array}{c}\text { Indicators to assess the level of development } \\
\text { of advanced digital and engineering } \\
\text { solutions, including binary and quantitative } \\
\text { indicators }\end{array}$ \\
\hline $\mathrm{IQ}_{\mathrm{U}}=\frac{\mathrm{IQ}_{\mathrm{U}}^{\mathrm{Com}}+I Q_{\mathrm{U}}^{\mathrm{Sol}}}{2}$ & $\mathrm{IQ}_{\mathrm{U}}=\frac{\sum_{\mathrm{K}=1}^{\mathrm{N}} l_{\mathrm{kij}}^{\mathrm{Com}}}{\mathrm{Ni}}$ & 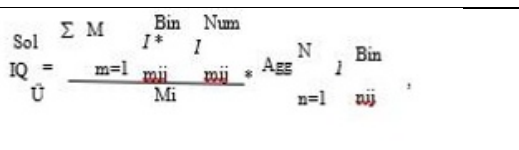 \\
\hline $\begin{array}{l}\mathrm{IQ}_{\ddot{\mathrm{U}}} \\
\text { - level of development } \\
\text { (evaluation of the } \\
\text { subindex) of the i- } \\
\text { direction of digital } \\
\text { transformation of } \\
\text { urban economy j city; } \\
\text { IQ Com } \\
\text { - average value of the } \\
\text { general indicators of } \\
\text { the evaluation of the } \mathrm{i} \\
\text { direction of the digital } \\
\text { transformation of the } \\
\text { urban economy of the } \\
\mathrm{j} \text { city; } \\
\text { IQ Sol } \\
\text { value of development } \\
\text { level of advanced } \\
\text { digital and } \\
\text { engineering solutions } \\
\text { corresponding to the i } \\
\text { direction of digital } \\
\text { transformation of } \\
\text { urban economy in the } \mathrm{j} \\
\text { city. }\end{array}$ & $\begin{array}{l}\text { I Com } \\
\text { kij - } \\
\text { normalized value } \mathrm{k} \text { of the } \\
\text { general evaluation } \\
\text { indicator i of the direction } \\
\text { of digital transformation } \\
\text { of urban economy j of the } \\
\text { Russian Federation; } \\
\text { Ni - the total number of } \\
\text { general evaluation } \\
\text { indicators of the level of } \\
\text { development i of the } \\
\text { direction of digital } \\
\text { transformation of the city } \\
\text { economy. }\end{array}$ & 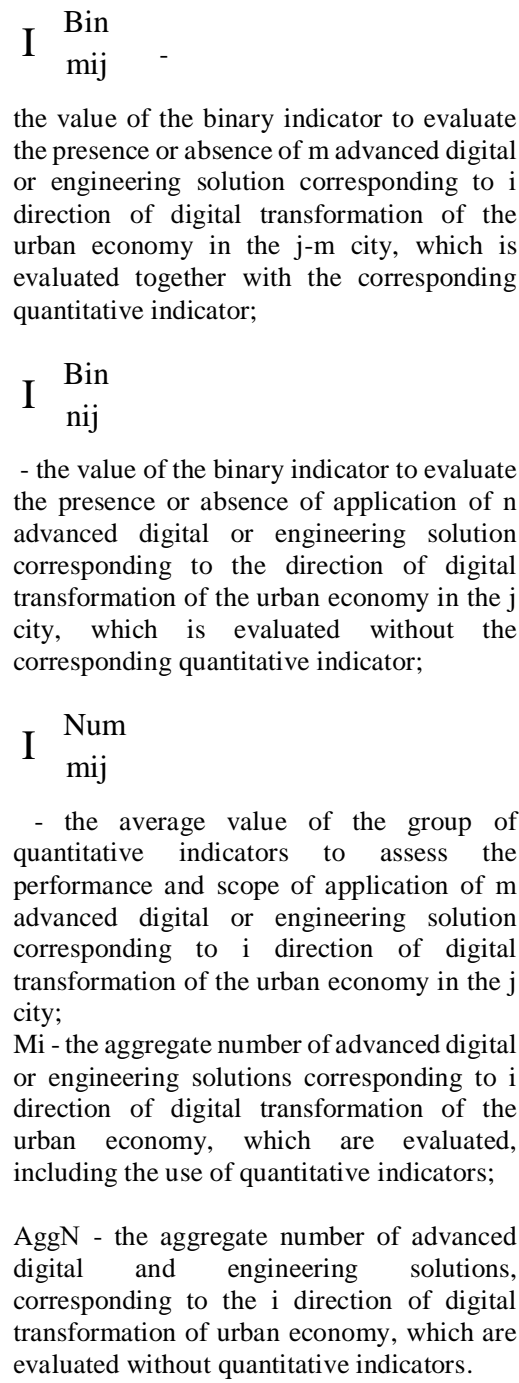 \\
\hline
\end{tabular}


Source: Order of the Ministry of Construction of Russia from 31.12.2019 N 924/pr "On Approval of the methodology for assessing the progress and efficiency of digital transformation of urban economy in the Russian Federation (IQ cities)" [10]

Table 2 presents evaluation indicators of advanced digital and engineering solutions in the field of tourism and services.

Table 2. Quantitative evaluation indicators of advanced digital and engineering solutions in the field of tourism and services.

\begin{tabular}{|c|c|c|c|}
\hline Indicator name & Calculation Formula & Basic indicators & $\begin{array}{c}\text { Indicator } \\
\text { description }\end{array}$ \\
\hline $\begin{array}{l}\text { Availability of } \\
\text { electronic cards of a } \\
\text { city resident and a } \\
\text { city guest }\end{array}$ & $\begin{array}{l}\text { Bin } \sum_{1.8}^{\mathrm{X}} F \\
\mathrm{~F}-\text { values of binary } \\
\text { evaluation indicators; } \\
\begin{array}{l}\mathrm{X} \text { - number of functions } \\
\text { (characteristics, } \\
\text { capabilities) }\end{array}\end{array}$ & $\begin{array}{l}\text { Calculated as the average value } \\
\text { of the following } \\
\text { indicators: } \\
\text { - Availability of electronic cards } \\
\text { of a city resident, which allow to } \\
\text { use public services and city } \\
\text { services, including payment for } \\
\text { travel on public transport; } \\
\text { - availability of electronic cards of } \\
\text { a city resident that allow receiving } \\
\text { targeted social support. }\end{array}$ & $\begin{array}{l}\text { The indicator } \\
\text { characterizes the } \\
\text { level of tourist } \\
\text { attractiveness of } \\
\text { the city and the } \\
\text { quality of life of } \\
\text { its citizens }\end{array}$ \\
\hline $\begin{array}{l}\text { The number of } \\
\text { unique active users of } \\
\text { electronic cards of a } \\
\text { city resident (who } \\
\text { performed at least } 1 \\
\text { action) per } 10 \\
\text { thousand people of } \\
\text { the city population }\end{array}$ & $\begin{array}{l}\text { Num ActUsel/N } \\
\mathrm{I}= \\
1.1 .8 \\
\text { (Unit/10 thousand people) }\end{array}$ & $\begin{array}{l}\text { ActUsel - the number of unique } \\
\text { active users of electronic cards of } \\
\text { a city resident (who have } \\
\text { performed at least } 1 \text { action), } \\
\mathrm{N} \text { - population of the city }\end{array}$ & $\begin{array}{l}\text { Indicator shows } \\
\text { the demand for } \\
\text { services among } \\
\text { the population }\end{array}$ \\
\hline $\begin{array}{l}\text { Availability of a } \\
\text { comprehensive } \\
\text { information system } \\
\text { for tourists and city } \\
\text { residents }\end{array}$ & $\begin{array}{l}\text { Bin } \sum_{2.8}^{\mathrm{X}} F \\
\mathrm{~F} \text { - values of binary } \\
\text { evaluation indicators; } \\
\begin{array}{l}\mathrm{X} \text { - number of functions } \\
\text { (characteristics, } \\
\text { capabilities) }\end{array}\end{array}$ & $\begin{array}{l}\text { Calculated as the average value of } \\
\text { the following indicators: } \\
\text { - availability of planning the city } \\
\text { tourist route on the city } \\
\text { information portal of services and } \\
\text { services for tourists and city } \\
\text { residents; } \\
\text { - the availability of hotel } \\
\text { reservations on the city } \\
\text { information portal services and } \\
\text { services for tourists and city } \\
\text { residents; } \\
\text { - the possibility of booking tours } \\
\text { of the city on the city information } \\
\text { portal services and services for } \\
\text { tourists and city residents; } \\
\text { - the availability of the city } \\
\text { information portal services and } \\
\text { services for tourists and residents } \\
\text { of the city functions to provide } \\
\text { OR-navigation system at cultural } \\
\text { heritage sites, including audio } \\
\text { guides; } \\
- \text { the availability of the city } \\
\text { information portal services and } \\
\text { services for tourists and residents } \\
\text { of the functions of providing a } \\
\text { system of OR-navigation at sites } \\
\text { of cultural heritage, including } \\
\text { mechanisms of augmented } \\
\text { reality; }\end{array}$ & $\begin{array}{l}\text { The indicator } \\
\text { characterizes the } \\
\text { extent to which } \\
\text { tourists and } \\
\text { citizens of the } \\
\text { city are provided } \\
\text { with convenient } \\
\text { sources of } \\
\text { information for } \\
\text { comfortable } \\
\text { movement and } \\
\text { services. }\end{array}$ \\
\hline
\end{tabular}




\begin{tabular}{|c|c|l|l|}
\hline & & $\begin{array}{l}\text { - availability on the city } \\
\text { information portal of services and } \\
\text { services for tourists and residents } \\
\text { of the function of informing about } \\
\text { the interactive and cultural and } \\
\text { exhibition events. }\end{array}$ & \\
\hline $\begin{array}{c}\text { Number of views of } \\
\text { the online portal of } \\
\text { the city for 10 } \\
\text { thousand people of } \\
\text { the city population }\end{array}$ & (Unit/10 thousand people) & $\begin{array}{l}\text { Num - population of the city } \\
I_{1.2 .8} \text { VieWonl-port } \\
\text { views of the online portal of the } \\
\text { city, }\end{array}$ & $\begin{array}{l}\text { The indicator } \\
\text { characterizes the } \\
\text { popularity of the } \\
\text { inty information } \\
\text { portal of services } \\
\text { and services for } \\
\text { tourists and city } \\
\text { residents. }\end{array}$ \\
\hline
\end{tabular}

Source: Order of the Ministry of Construction of Russia from 31.12.2019 N 924/pr "On Approval of the methodology for assessing the progress and efficiency of digital transformation of urban economy in the Russian Federation (IQ cities)" [10].

The field of recreation and tourism is multifaceted. The approved assessment methodology does not pay attention to digitalization in the provision of sanatorium services, as well as not defined the circle of persons responsible for digitalization. Table 3 presents quantitative indicators of evaluation of advanced digital and engineering solutions in the field of tourism and services by responsible organizations.

Table 3. Quantitative indicators of assessment of advanced digital and engineering solutions in the field of tourism and services.

\begin{tabular}{|c|c|c|c|}
\hline Indicator name & Calculation Formula & Basic indicators & Indicator description \\
\hline \multicolumn{4}{|c|}{ Responsible: health-resort (sanatorium) organizations } \\
\hline $\begin{array}{l}\text { Availability of } \\
\text { services that allow } \\
\text { a city resident (not } \\
\text { a guest) to make an } \\
\text { appointment to see } \\
\text { a doctor in a } \\
\text { sanatorium }\end{array}$ & $\begin{array}{l}\qquad I=\frac{\sum F}{N}, \\
\text { F - the number of patients } \\
\text { who have signed up in } \\
\text { electronic queue to the } \\
\text { doctors of the sanatorium; } \\
\text { N - the total number of } \\
\text { doctors in the sanatorium }\end{array}$ & $\begin{array}{l}\text { Calculated as the average value } \\
\text { of the following indicators: } \\
\text { - availability of an electronic } \\
\text { appointment with a health resort } \\
\text { (sanatorium) organization to see } \\
\text { a doctor for the residents of the } \\
\text { city }\end{array}$ & $\begin{array}{l}\text { The indicator } \\
\text { characterizes the } \\
\text { demand for the } \\
\text { services } \\
\text { sanatorium (health } \\
\text { resort) organizations }\end{array}$ \\
\hline $\begin{array}{l}\text { Availability of } \\
\text { services that allow } \\
\text { you to sign up for } \\
\text { procedures in the } \\
\text { sanatorium to avoid } \\
\text { queues }\end{array}$ & $\begin{array}{l}\qquad I=\frac{\sum F}{N}, \\
\begin{array}{l}\text { F - number of patients served } \\
\text { by electronic queue; } \\
\text { N - total number of patients } \\
\text { served by this service }\end{array}\end{array}$ & $\begin{array}{l}\text { Calculated as an average value } \\
\text { of the number of patients } \\
\text { enrolled by electronic queue, to } \\
\text { the total number of patients } \\
\text { served by this service }\end{array}$ & $\begin{array}{l}\text { The indicator } \\
\text { characterizes the } \\
\text { quality and } \\
\text { convenience of } \\
\text { services provided }\end{array}$ \\
\hline $\begin{array}{l}\text { Share of sanatorium } \\
\text { organizations } \\
\text { providing electronic } \\
\text { recording services to } \\
\text { the total number of } \\
\text { sanatoriums in the } \\
\text { city }\end{array}$ & $\begin{array}{l}\quad I=\mathrm{SOel} / \mathrm{SO} \\
\text { SOel - sanatorium (health } \\
\text { resort) organizations, } \\
\text { providing } \\
\text { electronic recording services, } \\
\text { SO - total number of } \\
\text { sanatoriums in the city }\end{array}$ & $\begin{array}{l}\text { Calculated as the ratio of } \\
\text { sanatorium organizations } \\
\text { providing electronic recording } \\
\text { services to the total number of } \\
\text { sanatoriums in the city, } \% \text {. }\end{array}$ & $\begin{array}{l}\text { The indicator } \\
\text { evaluates the level of } \\
\text { digital services } \\
\text { distribution in the } \\
\text { segment } \\
\text { sanatorium (health } \\
\text { resort) services }\end{array}$ \\
\hline \multicolumn{4}{|c|}{ Responsible: travel agencies (companies) } \\
\hline
\end{tabular}




\begin{tabular}{|c|c|c|c|}
\hline $\begin{array}{l}\text { Opportunity to } \\
\text { book tours on the } \\
\text { information portal } \\
\text { of services and } \\
\text { services for tourists } \\
\text { and city residents. }\end{array}$ & $\begin{array}{l}\qquad I=\frac{\sum F}{N}, \\
\text { F - number of tourists who } \\
\text { have booked a tour through } \\
\text { an electronic system; } \\
\text { N - the total number of } \\
\text { tourists who have received } \\
\text { this tour }\end{array}$ & $\begin{array}{l}\text { Calculated as an average of the } \\
\text { number of tourists who booked } \\
\text { a tour through an electronic } \\
\text { system, to the total number of } \\
\text { tourists who received the tour }\end{array}$ & $\begin{array}{l}\text { The indicator } \\
\text { characterizes the } \\
\text { extent to which } \\
\text { tourists and citizens } \\
\text { of the city are } \\
\text { provided with } \\
\text { convenient sources } \\
\text { of information for } \\
\text { receiving services. }\end{array}$ \\
\hline $\begin{array}{l}\text { Share of travel } \\
\text { agencies that provide } \\
\text { the opportunity to } \\
\text { book services } \\
\text { through the } \\
\text { electronic system, to } \\
\text { the total number of } \\
\text { travel agencies in the } \\
\text { city }\end{array}$ & $\begin{array}{l}\qquad I=\text { TAel/TA } \\
\text { TAel - travel agencies that } \\
\text { provide the opportunity to } \\
\text { book services through the } \\
\text { electronic system, } \\
\text { TA - total number of travel } \\
\text { agencies in the city }\end{array}$ & $\begin{array}{l}\text { Calculated as the ratio of travel } \\
\text { agencies providing the } \\
\text { opportunity to book services } \\
\text { through the electronic system } \\
\text { to the total number of travel } \\
\text { agencies in the city, } \% \text {. }\end{array}$ & $\begin{array}{l}\text { The indicator } \\
\text { evaluates the level } \\
\text { of digital services } \\
\text { distribution in the } \\
\text { segment of travel } \\
\text { agencies }\end{array}$ \\
\hline \multicolumn{4}{|c|}{ Responsible: hotels and similar accommodation facilities } \\
\hline $\begin{array}{l}\text { Availability of the } \\
\text { opportunity to book } \\
\text { city hotels on the } \\
\text { city information } \\
\text { portal of services } \\
\text { and services for } \\
\text { tourists and } \\
\text { residents of the } \\
\text { city. }\end{array}$ & $\begin{array}{l}\qquad=\frac{\sum F}{N}, \\
\text { F - number of tourists who } \\
\text { have booked a hotel through } \\
\text { an electronic system; } \\
\mathrm{N}-\text { the total number of } \\
\text { tourists who have arrived at } \\
\text { this hotel }\end{array}$ & $\begin{array}{l}\text { Calculated as an average of the } \\
\text { number of tourists who have } \\
\text { booked a hotel through an } \\
\text { electronic system, to the total } \\
\text { number of tourists who have } \\
\text { arrived at a given hotel. }\end{array}$ & $\begin{array}{l}\text { The indicator } \\
\text { characterizes the } \\
\text { extent to which } \\
\text { tourists and citizens } \\
\text { of the city are } \\
\text { provided with } \\
\text { convenient sources } \\
\text { of information for } \\
\text { receiving services. }\end{array}$ \\
\hline $\begin{array}{l}\text { Share of hotels that } \\
\text { provide the } \\
\text { opportunity to book } \\
\text { services via } \\
\text { electronic system, } \\
\text { to the total number } \\
\text { of hotels in the city }\end{array}$ & $\begin{array}{l}\quad I=\mathrm{Hel} / \mathrm{H} \\
\text { Hel - hotels that provide the } \\
\text { opportunity to book services } \\
\text { through an electronic system, } \\
\mathrm{H} \text { - total number of hotels in } \\
\text { the city }\end{array}$ & $\begin{array}{l}\text { Calculated as the ratio of hotels } \\
\text { providing the opportunity to } \\
\text { book services through the } \\
\text { electronic system, to the total } \\
\text { number of hotels in the city, } \% \text {. }\end{array}$ & $\begin{array}{l}\text { The indicator } \\
\text { estimates the level } \\
\text { of distribution of } \\
\text { digital services in } \\
\text { the segment of } \\
\text { hotels and similar } \\
\text { accommodation } \\
\text { facilities }\end{array}$ \\
\hline
\end{tabular}

Source: Compiled by the authors.

The indicators presented in Table 3 on the example of the recreation and tourism sector allow to estimate the degree of digital transformation of each organization.

\section{Conclusions}

"Smart Resort" - is a resort city that meets the following conditions:

- industries and activities are developing on the basis of the introduction of modern information and communication technologies;

- the driver of development is the sphere of recreation and tourism;

- compliance with the established indicators of digital transformation.

The evaluation indicators of digital transformation in the field of recreation and tourism, proposed by the authors, can be used in the implementation of competitive procurement and state subsidies. This will serve as an incentive for organizations to introduce digital technologies. 


\section{References}

1. Zhertovskaya E V, Yakimenko M V 2018 Fundamental researches 283

2. Innovations: tourism and digital economy http://www.rosinform.ru/top/180562innovatsii-turizm-i-tsifrovaya-ekonomika/.

3. Nam T and Pardo T A 2011 Proceedings of the 12th Annual International Digital Government Research Conference: Digital Government Innovation in Times of Challenges $\mathrm{p} 282$

4. Vanolo A 2014 Urban Studies 51(5) 883

5. Su K, Lee J Yi Fu H 2011 International Conference on Electronics, Communications and Control (ICECC) p 1028

6. Harrison C, Eckman B, Hamilton R, Hartswick P, Kalagnanam J, Paraszczak J, Williams P 2010 IBM J. Res. Dev. 541

7. Allam Z and Newman P 2018 Smart City 1(1) 4

8. Washburn D, Sindhu U, Balaouras S, Dines R A, Hayes N, Nelson L E 2009 Growth 171

9. Damery R P, Rosenthal-Sabrou K 2014 Smart City and Value Creation Smart City (Springer, Chum)

10. Order of the Ministry of Construction of Russia from 31.12.2019 N 924/pre http://www.consultant.ru/cons/cgi/online.cgi?req=doc\&base=EXP\&n=379313\#04418 2019155096053

11. 2019 The basic and additional requirements for smart cities (standard "Smart City") (Ministry of Construction of Russia) http://www.consultant.ru/document/cons_doc_LAW_319635/

12. Pivkina N Y 2019 Humanities. Herald of the Financial University 4

13. Gretzel U, Sigala M, Xiang Z et al 2015 Smart tourism: basics and developments. Electronic markets 25179

14. Bukhalis D and Amarangana A 2014 Information and communication technologies in tourism (Springer)

15. 2020 In Russia, the first "smart" city resort Zheleznovodsk

16. 2020 Sochi is one of the three most innovative cities in Russia

17. 2018 By 2024 Sochi will be a "Smart City"

18. Minov A 2020 "Smart Cities" need investors and startups http://niitc.ru/upload/medialibrary/296/29609984f6335325bdb4ef8625519550.pdf

19. Baranova A, Kegeyan S 2018 MATEC Web of Conferences 01027

20. Vorobey E, Borisova T 2018 MATEC Web of Conferences $\mathbf{0 1 0 2 3}$

21. Vasilenko I A, Egorova A N 2019 Public administration. Electronic Bulletin 77

22. 2018 Sochi has received the status of a "smart city" 